\title{
Adopsi Inovasi : Local Value Sebagai Faktor Pendorong Di Kawasan Minapolitan Kabupaten Kampar
}

\author{
${ }^{1}$ Adianto, ${ }^{2}$ Hasim As'ari, ${ }^{3}$ Geovani Meiwanda \\ Fakultas Ilmu Sosial dan Ilmu Politik Universitas Riau, Indonesia \\ ${ }^{1}$ Program Studi Administrasi Publik \\ e-mail: adianto@lecturer.unri.ac.id
}

\begin{abstract}
Abstrak
Tujuan penelitian ini untuk menganalisis secara komprehensif tentang faktor-faktor yang mendorong masyarakat mengadopsi inovasi yang dikenalkan di Kawasan Minapolitan Kabupaten Kampar. Penelitian ini dilaksanakan di Kabupaten Kampar yang telah ditetapkan sebagai Kawasan Minapolitan. Tehnik pengumpulan data dilakukan melalui wawancara dan observasi penelitian. Setalah data terkumpul dari setiap infoman penelitian, kemudian akan digunakan metode triangulasi dengan cek and cross cek terhadap hasil tanggapan yang diberikan informan penelitian. Jenis penelitian yang dipilih adalah penelitian kualitatif dengan pendekatan studi kasus yang bersifat deskriptif, yaitu prosedur pemecahan masalah yang diteliti dengan menggunakan cara memaparkan data yang diperoleh dari pengamatan kepustakaan dan pengamatan lapangan, kemudian dianalisa dan diinterprestasikan dengan memberikan kesimpulan. Hasil penelitian menemukan bahwa adopsi inovasi lokal yang berlangsung di Kawasan Minapolitan Desa Koto Mesjid mengandung nilai-nilai lokal yaitu nilai kekeluargaan nilai kebersamaan dan nilai senasip sepenanggungan. Keberadaan nilai-nilai lokal yang telah diwariskan oleh para lelehur ternyata mampu menjadi jembatan penghubung bagi masyarakat untuk dibimbing dan diarahkan dalam proses budidaya komoditas ikan patin.
\end{abstract}

Keywords: Inovasi, Adopsi Inovasi, Nilai Lokal dan Kawasan Minapolitan

\begin{abstract}
The purpose of this research is to analyse comprehensively about the factors that encourage the public to adopt innovations that are introduced in the Minapolitan Area of Kampar District. This research was conducted in Kampar District which has been designated as Minapolitan Area. Data collection techniques are conducted through interviews and research observations. After the data collected from each infoman research, then will be used method triangulation with check and cross check against the results of the response given the research informant. The type of research selected is qualitative research with a descriptive case study approach, which is the problem solving procedure that is researched using how to expose the data obtained from literature observation and field observation, then be analyzed and interorganized by concluding conclusions. The results found that the adoption of local innovations that took place in the Minapolitan Area of Koto Mesjid contains local values that are the value of family togetherness and value of a similar fate. The existence of local values that have been passed down by the melt is able to be a bridge for the community to be guided and directed in the process of cultivation of patin fish commodities.
\end{abstract}

Kata Kunci : Innovation, Adoption Innovation, Local Values and Minapolitan Area 


\section{PENDAHULUAN}

Pengembangan pertanian dan perikanan merupakan salah satu kekuatan inti (core business) perekonomian daerah yang selama ini baru dikelola sampai skala regional, padahal pertanian dan perikanan memiliki prospek dan mampu bersaing dalam skala nasional maupun internasional. Pengembangan kawasan Minapolitan dapat dijadikan alternatif solusi dalam pengembangan kawasan perdesaan untuk menghilangkan kesenjangan pembangunan dengan kawasan perkotaan, bahkan mampu mendukung perkembangan kawasan perkotaan. Disisi lain pengembangan kawasan Minapolitan diharapkan mampu mendorong interaksi yang kuat antara pusat kawasan Minapolitan dengan wilayah produksi pertanian. Pendekatan ini diharapkan mampu mendorong terjadinya pengolahan bahan baku produk pertanian sebelum dijual ke pasar yang lebih luas, sehingga nilai tambah tetap berada di Kawasan Minapolitan.

Kawasan minapolitan merupakan suatu bagian wilayah yang mempunyai fungsi utama ekonomi yang terdiri dari sentra produksi, pengolahan, pemasaran komoditas perikanan, pelayanan jasa, dan/atau kegiatan pendukung lainnya. Minapolitan dilakukan berdasarkan asas: 1). Demokratisasi ekonomi kelautan dan perikanan pro rakyat. 2). Keberpihakan pemerintah pada rakyat kecil melalui pemberdayaan masyarakat. 3). Penguatan peranan ekonomi daerah dengan prinsip daerah kuat maka bangsa dan Negara kuat. (Peraturan Menteri Kelautan dan Perikanan Nomor PER.12/MEN/2010 tentang Minapolitan)

Penetapan Kawasan Minapolitan bertujuan untuk : Pertama, meningkatkan produksi, produktivitas, dan kualitas produk kelautan dan perikanan. Kedua, meningkatkan pendapatan nelayan, pembudidaya ikan, dan pengolah ikan yang adil dan merata. Ketiga, mengembangkan kawasan minapolitan sebagai pusat pertumbuhan ekonomi di daerah. Sedangkan sasaran pelaksanaan Kawasan Minapolitan, yaitu:

1. Meningkatkan kemampuan ekonomi masyarakat kelautan dan perikanan skala mikro dan kecil,antara lain berupa:

a) Penghapusan dan/atau pengurangan beban biaya produksi, pengeluaran rumah tangga, dan pungutan liar.

b) Pengembangan sistem produksi kelautan dan perikanan efisien untuk usaha mikro dan kecil.

c) Penyediaan dan distribusi sarana produksi tepat gunadan murah bagi masyarakat.

d) Pemberian bantuan teknis dan permodalan.

e) Pembangunan prasarana untuk mendukung sistem produksi, pengolahan, dan/atau pemasaran produk kelautan dan perikanan.

2. Meningkatkan jumlah dan kualitas usaha kelautan dan perikanan skala menengah ke atas sehingga berdaya saing tinggi, antara lain berupa:

a) Deregulasi usaha kelautan dan perikanan.

b) Pemberian jaminan keamanan dan keberlanjutan usaha dan investasi.

c) Penyelesaian hambatan usaha dan perdagangan (tarif dan non-tarif barriers).

d) Pengembangan prasarana untuk mendukung sistem produksi, pengolahan, dan/atau pemasaran.

e) Pengembangan sistem insentif dan disinsentif ekspor-impor produk kelautan dan perikanan.

3. Meningkatkan sektor kelautan dan perikanan menjadi penggerak ekonomi regional dan nasional,antara lain berupa:

a) Pengembangan sistem ekonomi kelautan dan perikanan berbasis wilayah.

b) Pengembangan kawasan ekonomi kelautan dan perikanan di daerah sebagai pusat pertumbuhan ekonomi lokal.

c) Revitalisasi sentra produksi, pengolahan, dan/atau pemasaran sebagai penggerak ekonomi masyarakat. 
d) Pemberdayaan kelompok usaha kelautan dan perikanan di sentra produksi, pengolahan, dan/atau pemasaran. (Peraturan Menteri Kelautan dan Perikanan Nomor PER.12/MEN/2010 tentang Minapolitan)

Berdasarkan tujuan dan sasaran yang ingin dicapai oleh kawasan minapolitan, maka karakteristik kawasan minapolitan di Indonesia meliputi : Pertama, suatu kawasan ekonomi yang terdiri atas sentra produksi, pengolahan, dan/atau pemasaran dan kegiatan usaha lainnya, seperti jasa dan perdagangan. Kedua, mempunyai sarana dan prasarana sebagai pendukung aktivitas ekonomi. Ketiga, menampung dan mempekerjakan sumberdaya manusia di dalam kawasan dan daerah sekitarnya. Keempat, mempunyai dampak positif terhadap perekonomian di daerah sekitarnya. Penetapan karakteristik kawasan minapolitan ini menjadikan beberapa wilayah di Indonesia difokuskan sebagai kawasan minapolitan di bidang kelautan dan perikanan.

Kawasan Minapolitan yang terdapat di Provinsi Riau salah satunya terdapat di Kabupaten Kampar, penetapan ini tentunya diiringi dengan harapan pengembangan ekonomi masyarakat di wilayah tersebut. Sebab keberadaan Kawasan Minapolitan akan memberikan dampak kepada munculnya inovasi lokal yang dikembangkan untuk melakukan pengelolaan di bidang perikanan. Pengembangan inovasi lokal yang dilakukan bertujuan untuk merangsang tumbuhnya ekonomi lokal masyarakat yang melakukan pengelolaan di bidang perikanan pada Kawasan Minapolitan. Apalagi ketetapan tentang Kawasan Minapolitan yang dilakukan bagi Kabupaten Kampar sudah berlangsung cukup lama dan tentunya telah memiliki dinamika adopsi inovasi yang memunculkan faktor pendorong bagi masyarakat untuk mengadopsinya. Karena adopsi inovasi yang dilakukan akan memberikan efek pengembangan ekonomi lokal bagi masyarakat yang ada di wilayah sekitarnya. Tema adopsi inovasi lokal dan pengembangan ekonomi masyarakat ditetapkan untuk melihat eksistensi pengembangan Kawasan Minapolitan yang berbasis inovasi teknologi dan dampaknya dalam pengembangan ekonomi masyarakat di Kabupaten Kampar.

Perubahan sosial yang terjadi bagi masyarakat di Kawasan Minapolitan yang ada di Kabupaten Kampar, akibat adanya pengembangan inovasi lokal yang dilakukan dan diadopsi oleh masyarakat tentunya bisa saja memberikan efek terhadap pengembangan ekonomi masyarakat atau bahkan tidak memberikan efek perubahan sama sekali. Berdasarkan pemaparan tersebut, maka rumusan masalah dalam penelitian ini adalah: apa saja faktor-faktor yang mendorong masyarakat untuk memutuskan mengadopsi inovasi lokal di Kawasan Minapolitan Kabupaten Kampar?. Tujuan penelitian ini untuk menganalisis secara komprehensif tentang faktor-faktor yang mendorong masyarakat mengadopsi inovasi yang dikenalkan di Kawasan Minapolitan Kabupaten Kampar.

Inovasi merupakan istilah yang relatif baru apabila diukur dari perjalanan sejarah peradaban manusia. Istilah ini berasal dari bahasa latin innovare yang berarti berubah sesuatu yang menjadi baru. Istilah inovasi (innovation dan innovate) sendiri baru mulai dikenal dalam kosakata bahasa Inggris pada abad ke-16. Hanya saja pada masa itu, istilah inovasi lebih banyak diasosiasikan secara negatif sebagai troublemaker serta lebih identik dengan nuansa revolusi atau perubahan radikal yang membawa dampak yang sangat luar biasa, terutama terhadap kemapanan sosial politik serta dianggap mengancam struktur kekuasan. Sehingga rejim kekuasaan dan politik, serta otoritas keagamaan pada masa itu cenderung menolak segala hal yang berbau inovasi. Selanjutnya istilah innovative sendiri mulai luas dipergunakan banyak orang sejak abad ke-17 atau sekitar 100 tahun kemudian. Inovasi dipahami sebagai "creating of something new" atau penciptaan sesuatu yang baru. Istilah inovasi menemukan pengertian modernnya untuk pertama kali dalam Oxford English Dictionary edisi tahun 1939 yaitu "the act of introducing a new product into market”. Dalam hal ini inovasi dipahami sebagai proses penciptaan produk (barang atau jasa) baru, pengenalan metode atau ide baru atau penciptaan perubahan atau perbaikan yang incremental. (Yogi Suwarno, 2008) 
Dalam literatur modern, inovasi sendiri memiliki pengertian yang sangat beragam serta banyak perspektif yang mencoba memaknainya. Salah satu pengertian menyebutkan bahwa inovasi adalah kegiatan yang meliputi seluruh proses menciptakan dan menawarkan jasa atau barang baik yang sifatnya baru, lebih baik atau lebih murah dibandingkan dengan yang tersedia sebelumnya. Pengertian ini menekankan pemahaman inovasi sebagai sebuah kegiatan (proses) penemuan (invention). Sebuah inovasi dapat berupa produk atau jasa yang baru, teknologi proses produksi yang baru, sistem struktur dan administrasi baru atau rencana baru bagi anggota organisasi. Menurut Rogers (2003), salah satu penulis buku inovasi terkemuka, menjelaskan bahwa : "an innovation is an idea, practice, or object that is perceived as new by individual or other unit of adopter". Jadi inovasi adalah sebuah ide, praktek, atau objek yang dianggap baru oleh individu satu unit adopsi lainnya. Inovasi dapat merupakan sesuatu yang berwujud (tangible) maupun sesuatu yang tidak berwujud (intangible). Memaknai inovasi sebagai sesuai yang hanya identik dengan teknologi saja akan jadi menyempitkan konteks inovasi yang sebenarnya.

Penulis lain yaitu Albury (2003) secara lebih sederhana mendefinisikan inovasi sebagai "new ideas that work". Ini berarti bahwa inovasi adalah berhubungan erat dengan ide-ide baru yang bermanfaat. Inovasi dengan sifat kebaruannya harus mempunyai nilai manfaat. Sifat baru dari inovasi tidak akan berarti apa-apa apabila tidak diikuti dengan nilai kemanfaatan dari kehadirannya. Selanjutnya Albury secara rinci menjelaskan bahwa : "successful innovation is the creation and implementation of new processes, products, services, and methods of delivery which result in significant improvements in outcomes efficiency, effectiveness, or quality". Ini menjelaskan bahwa ciri dari inovasi yang berhasil adalah adanya bentuk penciptaan dan pemanfaatan proses baru, produk baru, jasa baru dan metode penyampaian yang baru, yang menghasilkan perbaikan yang signifikan dalam hal efisiensi, efektivitas maupun kualitas.

Pengertian inovasi diatas dapat disimpulkan bahwa inovasi dapat hadir dalam wujud pengetahuan, cara, objek, teknologi dan atau penemuan baru. Oleh karenanya sifat mendasar dari sebuah inovasi adalah sifat kebaruan (novelty). Untuk itu sebuah produk (barang atau jasa) dapat dikatakan sebagai produk inovatif apabila memang dipandang baru oleh pasarnya (publik). Namun demikian, sifat kebaruan ini biasanya hanya berlaku dalam konteks limitasi geografis yang artinya sesuatu yang baru di satu tempat belum tentu baru di tempat yang lain.

Keputusan adopsi inovasi adalah proses ketika individu atau unit adopsi yang disebut adopter menempuh tahapan-tahapan sejak mengetahui pertama sekali inovasi diperkenalkan yang diikuti implementasi ide-ide baru dan pemastian keputusan menerima atau menolak inovasi (Rogers, 1995). Di sisi lain, individu atau kelompok tidak begitu saja akan menerima ide-ide baru yang masih asing bagi mereka sehingga dibutuhkan suatu proses keputusan untuk mengadopsi inovasi.

Samsudin (1982) berpendapat bahwa adopsi adalah suatu proses yang dimulai dari keluarnya ideide dari satu pihak yang disampaikan kepada pihak kedua hingga diterimanya ide tersebut oleh masyarakat sebagai pihak kedua. Definisi ini memberikan pemahaman bahwa ketika individu menerima informasi tentang inovasi hingga memutuskan untuk mengadopsi inovasi tersebut, individu akan melalui beberapa tahapan atau proses. Tahapan dan proses yang dilalui merupakan bentuk penerimaan atau adopsi inovasi yang telah dikenalkan dalam sistem sosial.

Suatu inovasi yang diluncurkan kepada masyarakat membutuhkan waktu dan cara untuk diadopsi oleh masyarakat walaupun inovasi tersebut menguntungkan bagi masyarakat. Dibutuhkan adanya usaha untuk menyakinkan masyarakat agar dalam mengadopsi suatu inovasi, mereka tidak ragu-ragu. Oleh karena itu, perlu cara dan metode tertentu dalam difusi inovasi pada suatu kelompok masyarakat, baik dengan pendekatan perseorangan maupun dengan pendekatan kelompok. Margono Slamet (1978) memaparkan proses adopsi adalah proses yang terjadi sejak pertama sekali seseorang tersebut mengadopsi (menerima, menerapkan, menggunakan hal baru tersebut). Penerimaan atau penolakan suatu 
inovasi adalah keputusan yang dibuat oleh seseorang. Untuk mengadopsi suatu inovasi, diperlukan jangka waktu tertentu dari mulai seseorang mengetahui sesuatu yang baru hingga terjadi adopsi.

Adopsi inovasi merupakan suatu proses mental atau perubahan perilaku baik yang berupa pengetahuan (cognitive), sikap (affective), maupun keterampilan (psychomotor) pada diri seseorang sejak ia mengenal inovasi sampai memutuskan untuk mengadopsinya setelah menerima inovasi (Rogers dan Shoemaker, 1971). Hal senada disampaikan oleh Soekartawi (dalam Agustina Abdullah, 2008) yang menyatakan bahwa adopsi merupakan proses mental dalam diri seseorang melalui pertama kali mendengar tentang suatu inovasi sampai akhirnya mengadopsi.

Levis (1996) mengemukakan bahwa adopsi dapat diartikan sebagai penerapan atau penggunaan suatu ide atau alat teknologi baru yang disampaikan lewat pesan komunikasi pada umumnya adalah penyuluhan. Adopsi merupakan rangkaian kegiatan yang dilakukan oleh seseorang terhadap sesuatu inovasi sejak mengenal, menaruh minat, menilai sampai menerapkan inovasi yang diterima. Adopsi dalam proses penyuluhan menurut Mardikanto (2010) pada hakikatnya dapat diartikan sebagai proses perubahan perilaku baik yang berupa pengetahuan, sikap maupun keterampilan pada diri seseorang setelah menerima inovasi yang disampaikan oleh penyuluh kepada masyarakat sasarannya. Dengan demikian, inovasi tidak hanya diadopsi sebagai sesuatu yang baru, tetapi merupakan nilai baru yang dapat mendorong terjadinya pembaruan dalam masyarakat atau lokalitas tertentu.

Adopsi juga dapat diartinya sebagai tingkat penerapan komponen inovasi oleh individu. Herianto (dalam Yohanes Geli Bulu, 2011) menjelaskan bahwa dari sisi intensitas, adopsi adalah tingkat penggunaan inovasi. Adopsi suatu inovasi biasanya diukur dari persentase penerapan komponen inovasi dari usaha tani tertentu ada persatuan luas lahan. Tingkat adopsi inovasi dapat diukur dari kualitas dan kuantitas adopsi. Kualitas adopsi diartikan sebagai ketepatan dalam menerapkan komponen inovasi dari usaha tani tertentu secara sempurna. Sementara itu, kuantitas adopsi adalah jumlah penerapan komponen inovasi dari usaha tani tertentu sesuai anjuran. Pada situasi kondisi tertentu atau kondisi dari pengadopsi itu yang tidak memungkinkan, tidak semua komponen inovasi dari usaha tani tertentu dapat diadopsi. Situasi kondisi yang dimaksudkan adalah kondisi sumber daya alam (iklim, ketersediaan air, pola curah hujan, kesuburan tanah, topografil lahan), sosial, serta ekonomi dan budaya. Berdasarkan situasi kondisi tersebut, kemungkinan dari beberapa komponen inovasi dimodifikasi sehingga berpengaruh terhadap kualitas adopsi.

Pemikiran tentang adopsi inovasi dapat disimpulkan sebagai proses mental dan proses perubahan perilaku yang terjadi pada setiap individu untuk menerima dan menolak ide, gagasan, pengetahuan, teknologi, dan penemuan baru. Proses mental dalam adopsi inovasi hadir karena adanya keinginan dari diri individu itu berdasarkan proses panca indera yang dimilikinya. Sementara itu, proses perubahan perilaku dalam adopsi inovasi hadir karena adanya keinginan individu untuk mempelajari sesuatu yang baru akibat dari kebutuhan individu tersebut. Oleh karenanya, adopsi inovasi dapat terjadi pada setiap individu akibat dari kedua proses tersebut sehingga nantinya dapat memberikan perubahan bagi diri individu tersebut dalam lingkungannya.

Bagi seorang petani menentukan suatu pilihan terhadap hadirnya suatu inovasi merupakan proses panjang yang harus dilalui sebelum memutuskan untuk menerima (adoption) maupun menolak (rejection) inovasi tersebut. Keputusan inovasi merupakan suatu tipe pengambilan keputusan yang khas karena mereka harus memilih alternatif baru (inovasi) dan meninggalkan teknologi lama. (Jauhari Efendy dan Yanter Hutapea, 2010)

Proses pengambilan keputusan untuk melakukan adopsi inovasi adalah sebagai berikut. (Rogers and Shoemaker, 1971) "The innovation decision process is the mental process throught which an individual passes from first knowledge of an innovation to a decision to adop or reject and tc confirmation of this decision". Definisi ini menjelaskan bahwa terdapat dua elemen penting yang perlu diperhatikan dalam adopsi inovasi. Pertama, adanya sikap mental untuk melakukan adopsi inovasi dan Kedua, adanya 
konfirmasi dari keputusan yang telah diambil. Oleh karena itu, dalam proses pengambilan keputusan untuk melakukan adopsi inovasi, sangat diperlukan adanya komitmen dari adopter dan perlu dijaga konsistensinya. Hal ini perlu didasarkan atas kemampuan yang dimiliki oleh calon adopter dalam rangka proses adopsi inovasi. Penerimaan atau penolakan suatu inovasi adalah keputusan yang dibuat oleh seseorang. Keputusan inovasi adalah proses mental sejak seseorang mengetahui adanya inovasi sampai mengambil keputusan untuk menerima atau menolaknya kemudian mengukuhkannya.

\section{METODE}

Jenis penelitian yang dipilih adalah penelitian kualitatif dengan pendekatan studi kasus yang bersifat deskriptif, yaitu prosedur pemecahan masalah yang diteliti dengan menggunakan cara memaparkan data yang diperoleh dari pengamatan kepustakaan dan pengamatan lapangan, kemudian dianalisa dan diinterprestasikan dengan memberikan kesimpulan. Penelitian ini memilih dan menetapkan lokasi penelitiannya di Kabupaten Kampar Kecamatan XIII Koto Kampar sebagai salah satu Kawasan Minapolitan di Provinsi Riau. Penelitian ini menetapkan informan penelitian sebagai sumber informasi untuk memperoleh data yang dibutuhkan dalam penelitian dengan menggunakan tehnik purposive sampling. Informan dalam penelitian ini adalah : 1). Informan kunci adalah orang yang mengetahui permasalahan penelitian secara mendalam. Adapun yang menjadi informan kunci dalam penelitian ini adalah masyarakat di Kawasan Minapolitan. 2). Informan pelengkap adalah orang yang dianggap mengetahui permasalahan penelitian, walaupun individu tersebut tidak terlibat secara langsung terhadap permasalahan penelitian tersebut. Adapun yang menjadi informan pelengkap dalam penelitian ini adalah Pengelola Kawasan Minapolitan dan Aparatur Desa.

Tehnik pengumpulan data dilakukan melalui wawancara dan observasi penelitian. Setalah data terkumpul dari setiap infoman penelitian, kemudian akan digunakan metode triangulasi dengan cek and cross cek terhadap hasil tanggapan yang diberikan informan penelitian. Tehnik triangulasi yang dilakukan adalah triangulasi dengan sumber data. Cara ini dilakukan dengan membandingkan dan mengecek baik derajat kepercayaan suatu informasi yang diperoleh melalui waktu dan cara yang berbeda.

\section{HASIL DAN PEMBAHASAN}

\section{Karakteristik Wilayah}

Desa Koto Mesjid adalah nama desa yang terletak di Wilayah Kecamatan XIII Koto Kampar dan sebagai Kawasan Minapolita Kabupaten Kampar Provinsi Riau. Karakteristik wilayah desa ini berada di ketinggian < 500 mdpl dengan bentuk lahan landai sampai bergunung dan cukup jauh dari aliran sungai. Wilayah desa ini sebagian besar merupakan daerah berbukit dan bergunung dengan lereng curam dan sangat curam. Daerah berbukit dan bergunung, terutama dijumpai di bagian barat/selatan yang merupakan bagian dari Bukit Barisan. Realitas wilayah desa yang berada di perbukitan atau dataran tinggi menyebabkan wilayah ini kesulitan pasokan air. Apabila ingin membuat sumur sebagai sumber air bagi kehidupan, warga membutuhkan penggalian atau pengeboran tanah yang cukup dalam sampai dengan kedalaman kurang lebih 60-70 meter baru dapat menemukan sumber air. Akan tetapi, sebaliknya, wilayah desa yang berada di wilayah yang landai atau lembah memiliki potensi air yang baik, yang sering disebut oleh masyarakat dengan istilah artesis. Artesis merupakan air yang keluar dengan sendirinya dari dalam tanah apabila dilakukan penggalian sehingga tidak membutuhkan pengeboran yang dalam.

Keunikan wilayah desa yang dimiliki dengan dasar perbukitan yang sulit air dan dasar lembah atau landai yang artesis memberikan dampak positif dan negatif yang besar bagi kecepatan dan 
kelancaran masyarakat untuk memutuskan adopsi inovasi teknologi bidang perikanan. Bagi masyarakat yang memiliki karakteristik lahan yang perbukitan, mereka akan mengandalkan air tadah hujan untuk mengisi kolam budidayanya dalam praktik inovasi budidaya komoditas ikan patin. Kondisi itu akan sangat menghambat periode pembudiyaan yang dilakukan oleh masyarakat pembudidaya. Mereka harus menunggu air hujan memenuhi kolam budidayanya sebelum dapat mempraktikkan budidaya komoditas ikan patin sesuai dengan inovasi yang diperkenalkan. Sementara itu, apabila masyarakat membuatkan sumur sebagai sumber air untuk mengisi kebutuhan air dalam kolam budidaya komoditas ikan patin, tentunya dibutuhkan modal yang besar guna memfasilitasi kegiatan budidaya komoditas ikan patin. Realitas ini terjadi di wilayah Dusun I Pincuran Bilah dan Dusun II Pincuran Gading sehingga hanya sedikit masyarakat yang berada di wilayah dusun tersebut yang mengadopsi inovasi teknologi budidaya komoditas ikan patin. Mereka beralasan bahwa lahan yang ada tidak mendukung untuk melakukan budidaya komoditas ikan patin. Efeknya masyarakat di wilayah dusun tersebut lebih cenderung bertahan hidup sebagai petani karet yang bibitnya diberikan oleh pemerintah sebagai kompensasi program transmigrasi lokal yang telah diikutinya. Selain sebagai petani karet, ada masyarakat di wilayah dusun itu yang berprofesi sebagai buruh dalam pengelolaan produk komoditas ikan patin di Kawasan Minapolitan yang telah disediakan oleh pemerintah.

Hal berbeda dengan masyarakat yang berdomisili di wilayah yang memiliki dasar lembah dan landai sehingga mereka mempunyai potensi lahan artesis. Wilayah desa yang memiliki potensi lahan artesis terletak pada Dusun III Kampung Baru 1 dan Dusun IV Kampung Baru 2. Mayoritas masyarakat yang berdomisili di wilayah dusun ini memanfaatkan lahannya untuk mengadopsi inovasi teknologi bidang perikanan dalam berbudidaya komoditas ikan patin. Fakta ini dikarenakan dukungan lahan yang dimiliki menjadi salah satu modal dasar bagi masyarakat untuk memutuskan mengadopsi inovasi teknologi yang sudah dikenalkan. Sebagaimana diketahui, dukungan lahan yang produktif akan menjadi salah satu syarat bagi lancarnya proses adopsi inovasi teknologi yang dilakukan oleh masyarakat. Hal itu karena dalam memulai pembudidayaan komoditas ikan patin, masyarakat tidak perlu mengeluarkan modal yang terlalu besar untuk mempersiapkan kolam budidayanya, sebab alam telah menyediakan lahan yang memiliki potensi sesuai dengan kebutuhan berbudidaya.

Desa ini memiliki empat dusun, yaitu Dusun I Pincuran Bilah, Dusun II Pincuran Gading, Dusun III Kampung Baru 1, dan Dusun IV Kampung Baru 2. Sementara itu, jarak desa dengan pusat Pemerintahan Kecamatan adalah 13 km, jarak ke pusat Pemerintahan Kabupaten adalah 43 km, dan dari jarak ke pusat Pemerintahan Provinsi adalah $93 \mathrm{~km}$. Karakteristik wilayah yang berbeda antara dua wilayah dusun di desa tersebut memberikan efek positif dan negatif bagi kelancaran dan kecepatan masyarakat dalam mengadopsi inovasi teknologi budidaya komoditas ikan patin.

\section{Karekteristik Masyarakat}

Masyarakat Desa Koto Mesjid merupakan masyarakat dari program transmigrasi lokal yang dilakukan oleh pemerintah daerah pada Tahun 1992 akibat adanya pembangunan pembangkit listrik tenaga air (PLTA) satu-satunya di Provinsi Riau. Sebelum mengikuti program transmigrasi lokal, masyarakat ini mendiami wilayah dengan karakteristik dataran rendah dan berada di daerah aliran sungai (DAS) di sepanjang Sungai Kampar yang menghubungkan Provinsi Sumatera Barat dengan Provinsi Riau. Karakteristik wilayah seperti itu memberikan kegiatan mata pencaharian utama masyarakatnya sebagai pencari ikan di sungai, yaitu perikanan tangkap, seperti memancing, menjaring atau menjala dan memasang bubuh. Kegiatan mencari ikan di sungai menjadi sumber pendapatan utama bagi masyarakat untuk memenuhi kebutuhan hidup keluarganya. DAS Kampar memiliki potensi ikan lokal yang melimpah dan menjadi ciri khas wilayah tersebut, seperti ikan baung, ikan tapah, ikan toman, ikan selais, ikan patin, ikan gurami, ikan lele, dan ikan gabus. Harga komoditas ikan lokal yang dihasilkan oleh DAS Kampar sangatlah tinggi di pasaran sehingga sangat mampu untuk mendukung perekonomian masyarakat. 
Kebijakan pembangunan PLTA di Provinsi Riau pada Tahun 1992 membawa dampak kepada seluruh desa yang berada di DAS Kampar karena mereka harus direlokasi ke daerah lain upaya mendukung program pemerintah menyediakan energi listrik bagi masyarakat. Ada sekitar delapan desa yang akan direlokasi untuk mendukung program pemerintah tersebut, termasuk Desa Pulau Gadang. Awalnya proses relokasi yang dilakukan mendapat perlawanan atau penolakan dari masyarakat karena daerah yang ditetapkan sebagai kawasan transmigrasi lokal sangat berbeda dengan karakteristik wilayah sebelumnya. Karakteristik wilayah baru adalah perbukitan, dataran tinggi, sulit air, dan jauh dari sungai. Realitas tersebut tentunya akan mengubah pola mata pencaharian masyarakat yang sangat mereka andalkan, yaitu sebagai pencari ikan di DAS Kampar. Kekhawatiran itu membuat adanya penolakan relokasi yang dilakukan oleh pemerintah dari masyarakat calon peserta transmigrasi lokal. Apalagi program transmigrasi lokal yang dilakukan akan mengubah pola mata pencaharian masyarakat dari pencari ikan di sungai menjadi petani karet. Fakta inilah yang mendasari lamanya waktu yang diperlukan untuk proses relokasi dan adanya tekanan yang diberikan oleh pemerintah kepada masyarakat untuk segera pindah.

Kepindahan masyarakat Desa Pulau Gadang ke tempat yang baru dengan karakteristik wilayah perbukitan, dataran tinggi, sulit, air dan jauh dari sungai dilakukan dengan keterpaksaan. Hal itu karena masyarakat terpaksa harus pindah dan menerima kompensasi yang diberikan pemerintah berupa rumah papan layak huni, lahan karet seluas 2,5 ha, lahan pekarangan 0,5 ha, dan jaminan hidup selama dua tahun. Dengan kompensasi yang diberikan inilah, masyarakat Desa Pulau Gadang menempati wilayah barunya kemudian menamakan desa baru itu seperti nama desa tempat awal masyarakat berasal, yaitu Desa Pulau Gadang. Setelah pindah ke desa yang baru, masyarakat mulai menjalani aktivitasnya sebagai petani karet di lahannya yang telah disediakan oleh pemerintahlokal tersebut.

Pola kehidupan yang berubah secara signifikan membuat masyarakat harus dapat menyesuaikan dirinya dengan kegiatan ekonomi yang baru. Namun, rendahnya pengetahuan, keterampilan, dan pengalaman yang dimiliki masyarakat tentang bertani karet membuat pertanian karet yang mereka miliki tidak terkelola dengan baik. Kondisi itu membuat kehidupan ekonomi masyarakat dari waktu ke waktu semakin menurun atau tidak baik karena mereka hanya mengandalkan jaminan hidup yang disediakan oleh pemerintah dalam memenuhi kebutuhan hidup keluarganya. Ketidakmampuan masyarakat mengelola mata pencaharian barunya berjalan sampai hampir menjelang habisnya jaminan hidup yang diberikan oleh pemerintah. Dengan kata lain, kehidupan masyarakat yang hanya mengandalkan jaminan hidup yang diberikan sampai pada ambang batas level kemiskinan.

Keterpurukan ekonomi, terutama dalam hal pendapatan, merangsang beberapa anggota masyarakat segera mencari sumber ekonomi baru untuk dapat menopang dan memenuhi kebutuhan hidup keluarganya. Langkah awal yang mereka lakukan untuk mencari sumber ekonomi baru adalah dengan kembali kepada kearifan lokalnya, yaitu sebagai pencari ikan tangkap di sungai. Namun, posisi sungai desa mereka yang baru ini sangatlah jauh dan hasil tangkapan yang diperoleh masyarakat tidak sama seperti pada waktu di desa yang lama karena sungai terdekat di desa hanya merupakan sungai kecil yang potensi ikan lokalnya sedikit. Upaya yang dilakukan ini tentunya tidak maksimal untuk membantu sektor pendapatan masyarakat dalam memperbaiki keterpurukan ekonominya. Oleh karena itu, masyarakat tetap membutuhkan alternatif kegiatan lain sebagai kegiatan mata pencaharian baru untuk memenuhi penerimaan sektor pendapatan yang dibutuhkan oleh keluarga.

Proses pencarian mata pencaharian baru dari masyarakat dimulai dari inisiatif masyarakat untuk membuat kolam ikan di sekitar areal tempat tinggalnya. Upaya penemuan mata pencarian baru yang dilakukan oleh masyarakat dengan membuat kolam ikan di sekitar pekarangan rumahnya mendapat perhatian dan dukungan dari Pemerintah Daerah Kabupaten Kampar. Dukungan yang diberikan adalah dengan memfasilitasi masyarakat membuat kolam ikan di sekitar lingkungan tempat tinggalnya dan memberikan bibit ikan sebagai modal dasar dalam pembudidayaan. Bantuan fasilitasi yang diberikan 
ternyata tidak semuanya dapat termanfaatkan oleh masyarakat karena ada desa dengan karakteristik wilayah di perbukitan yang rendah dan perbukitan yang tinggi. Dengan demikian, setiap kolam yang dibangun di wilayah desa yang berada di perbukitan yang rendah menghasilkan kondisi tanah yang artesis dan wilayah desa yang berada pada perbukitan yang tinggi menghasilkan kondisi tanah yang tidak artesis. Kondisi tanah yang artesis berarti bahwa setiap tanah yang digali untuk kolam ikan akan mengeluarkan air sendiri dari dalam kolam tersebut sehingga tidak perlu menunggu air hujan untuk mengisi air kolam budidayanya. Sebaliknya, bagi wilayah yang tidak artesis, masyarakatnya harus menunggu air hujan untuk mengisi air kolam budidayanya.

Proses berbudidaya ikan dengan sistem kolam yang diprakarsai oleh masyarakat dan pemerintah daerah sebagai upaya penemuan sumber mata pencaharian baru ternyata tidak berjalan dengan lancar karena rendahnya pengetahuan, keterampilan, dan pengalaman masyarakat dalam berbudidaya ikan dengan sistem kolam. Apalagi dengan karakteristik wilayah yang perbukitan, sulit air, dan tingkat keasaman $(\mathrm{pH})$ tanah yang rendah, masyarakat belum mampu menemukan komoditas ikan yang tepat untuk dibudidayakan. Fakta inilah yang membuat proses budidaya ikan dengan sistem kolam sebagian besar gagal dan tidak dapat dijadikan sandaran sebagai sumber mata pencaharian baru. Kegagalan masyarakat dalam berbudidaya ikan dengan sistem kolam semakin memperburuk kondisi ekonomi masyarakat yang ingin mencari sumber pendapatan baru.

Kondisi ekonomi yang tidak semakin membaik yang disebabkan oleh ketidakmampuan masyarakat menemukan sumber pendapatan baru menjadi sebuah permasalahan yang rumit. Masyarakat yang telah disiapkan oleh pemerintah sebagai petani karet ternyata tidak berhasil mengelola perkebunan karet yang diberikan sehingga tidak dapat menghasilkan sesuai dengan waktu yang ditentukan. Solusi penemuan sumber ekonomi baru dengan memberikan kegiatan kepada masyarakat untuk membudidayakan ikan dengan sistem kolam juga tidak berjalan dengan lancar. Realitas inilah yang akhirnya dijawab oleh pemerintah daerah dengan mengirimkan tenaga penyuluh atau agent of change untuk membantu masyarakat membudidayakan ikan dengan sistem kolam. Pemerintah daerah melalui BPTP (Badan Pengembangan Teknologi Perikanan) mengirimkan penyuluh lapangan atau agent of change untuk menjawab permasalahan budidaya ikan dengan sistem kolam. Masalah yang hendak dipecahkan adalah dari pemilihan komoditas ikan yang tepat, pengelolaan kolam, pembibitan ikan, dan pembuatan pakan ikan. Keberadaan penyuluh diharapkan segera dapat menemukan solusi akan permasalahan budidaya ikan dengan sistem kolam yang dilakukan oleh masyarakat.

Kegiatan eksperimen yang dilakukan oleh penyuluh dalam upaya menemukan komoditas ikan yang tepat dilaksanakan beberapa kali. Hingga akhirnya penyuluh merekomendasikan komoditas ikan patin yang paling tepat untuk dibudidayakan dengan karakteristik wilayah perbukitan, sulit air, dan $\mathrm{pH}$ tanah yang rendah. komoditasIkan patin secara teknis merupakan jenis ikan yang hidup tidak memerlukan air yang terlalu banyak, tidak perlu air mengalir untuk kolamnya, dan memiliki daya tahan hidup yang lebih baik dibandingkan dengan ikan air tawar lainya. Apalagi dengan tingkat pencahayaan yang masuk ke dalam air sangatlah rendah, sangat cocok bagi spesies ikan patin untuk dikembangkan. Hasil rekomendasi yang telah disampaikan oleh penyuluh itu tidak semerta-merta menumbuhkan kepercayaan (trust) dan keyakinan kepada masyarakat untuk mengikutinya. Bukan tanpa alasan ketika masyarakat tidak langsung menerimanya karena sebelumnya masyarakat juga pernah mencoba budidaya komoditas ikan patin dan gagal. Kegagalan yang dialami oleh masyarakat dalam membudidayakan komoditas ikan patin menjadi ukuran mereka untuk tidak menerima hasil rekomendasi yang diberikan oleh penyuluh.

Ketidakberpihakan masyarakat terhadap hasil rekomendasi yang ditemukan menyulut keinginan penyuluh untuk membuktikan hasil rekomendasi yang telah disampaikannya itu. Hasil rekomendasi itu nantinya dapat menjawab dan menjadi solusi bagi masyarakat yang sedang mencari sumber pendapatan baru guna memenuhi kebutuhan hidup keluarganya. Keinginan penyuluh itu direalisasikan dengan mengundurkan diri sebagai penyuluh dan melakukan hubungan sosial dengan salah satu masyarakat 
melalui proses perkawinan dengan tujuan untuk memperoleh lahan sebagai media pembuktian rekomendasi yang telah dihasilkan. Pembuktian hasil rekomendasi yang telah diusulkan langsung dilakukan oleh mantan penyuluh atau inovator awal dengan sentuhan inovasi dalam berbudidaya komoditas ikan patin. Sentuhan inovasi yang dilakukan inovator awal dalam membudidayakan komoditas ikan patin adalah dengan memperhitungkan secara teknis luasan kolam ikan dengan jumlah bibit yang akan dimasukkan. Dengan demikian, komoditas ikan patin yang dipelihara dapat berkembang dan menghasilkan panen yang memuaskan. Praktik budidaya komoditas ikan patin yang dilakukan oleh inovator awal berhasil memperoleh hasil panen yang maksimal. Informasi keberhasilan tersebut secara cepat menyebar kepada seluruh masyarakat di wilayah desa tersebut.

Namun, ternyata pembuktian yang telah dilakukan oleh inovator awal tidak juga serta-merta memberikan kepercayaan (trust) dan keyakinan kepada masyarakat untuk segera mengikuti pola budidaya komoditas ikan patin dengan sistem kolam. Masyarakat masih menunggu apakah budidaya komoditas ikan patin dapat memberikan janji keuntungan atau reward kepada mereka. Hal itu dikarenakan modal untuk berbudidaya komoditas ikan patin cukup besar. Sebab bibit ikan masih dibeli dari Pulau Jawa dan kehidupan masyarakat juga sedang dalam keterpurukan ekonomi yang luar biasa. Realitas tersebut membuat masyarakat menunda mengikuti pola berbudidaya komoditas ikan patin yang telah berhasil dilakukan oleh inovator awal. Akhirnya untuk tahap awal, hanya beberapa anggota masyarakat yang memiliki kekuatan modal saja yang dapat mengikuti pola budidaya komoditas ikan patin. Itu pun adalah kalangan masyarakat yang memiliki hubungan keluarga dengan inovator awal yang terlebih dulu telah berhasil mempraktikkan budidaya komoditas ikan patin.

Proses adopsi inovasi teknologi yang dilakukan oleh beberapa masyarakat ternyata juga memberikan hasil yang memuaskan. Hal itu karena proses budidaya komoditas ikan patin yang dilakukan mengikuti bimbingan dan arahan dari inovator awal yang telah terlebih dulu mempraktikkannya. Praktik budidaya komoditas ikan patin ternyata memberikan janji keuntungan kepada para pembudidaya dan memberikan solusi terhadap masalah penemuan sumber ekonomi baru.

\section{Local Value Sebagai Faktor Pendorong Adopsi Inovasi}

Nilai-nilai lokal adalah suatu kebiasaan dan tradisi yang berkembang akibat dari adaptasi yang berlangsung dengan lingkungan tempat tinggalnya. Setiap kehidupan masyarakat pada suatu wilayah setidaknya memiliki nilai-nilai lokal yang dijunjung tinggi untuk dipatuhi. Oleh karenanya, keberadaan nilai-nilai lokal di dalam kehidupan bermasyarakat menjadi alat kontrol dalam pola interaksi yang dilakukan. Akibatnya, setiap anggota masyarakat tanpa menyadari harus berusaha mematuhi dan menghormati nilai-nilai lokal yang telah terpelihara secara turun-temurun oleh setiap generasi masyarakat yang ada. Nilai-nilai lokal yang berkembang dan tumbuh dalam kehidupan masyarakat nantinya akan membentuk sebuah kearifan lokal yang dapat menjadi karakteristik tersendiri bagi masyarakat tersebut. Realitas tersebut menunjukkan bahwa hampir setiap kehidupan masyarakat pada suatu wilayah yang masih kental dengan kebiasaan dan tradisi sebagai wujud dari kearifan lokal akan terus memelihara nilainilai lokalitas yang tela diyakininya itu.

Desa Koto Mesjid yang secara struktur wilayah berada dekat dengan perbatasan Provinsi Riau dengan Provinsi Sumatera Barat memiliki karakteristik wilayah perbukitan dan jauh dari aliran sungai. Pada dasarnya daerah ini merupakan wilayah yang diperuntukkan bagi masyarakat program transmigrasi lokal yang wilayahnya digunakan oleh pemerintah untuk pembangunan pembangkit listrik tenaga air (PLTA). Masyarakat di desa ini mayoritas masyarakat yang berasal dari Suku Melayu Daratan. Suku Melayu Daratan yang ada di Kabupaten Kampar pada umumnya merupakan keturunan dari Suku Minangkabau. Fakta itu berdasarkan pada hampir seluruh kebudayaan yang berkembang di Suku Melayu Daratan sama persis dengan budaya Suku Minangkabau. Di antara budaya itu adalah garis keturunan yang bersifat matrialisme, nilai adat basandi syarak, syarak basandi kitabullah, dan memiliki ninik mamak. 
Nilai-nilai lokal yang dianut oleh masyarakat tidak sepenuhnya bersumber dari budaya Minangkabau yang menjadi leluhurnya. Akan tetapi, ada beberapa nilai-nilai budaya Minangkabau yang dijadikan dasar dalam berkembangnya nilai-nilai lokal yang tumbuh di dalam kehidupan masyarakat. Nilai-nilai lokal yang dimiliki oleh masyarakat, seperti nilai kekeluargaan, nilai kebersamaan dan nilai senasip sepenangungan terdapat dalam nilai adat basandi syarak, syarak basandi kitabullah. Ketiga nilainilai lokal yang berkembang dalam kehidupan masyarakat inilah yang menjadi pengikat kuat bagi keberlangsungan kegiatan dalam bidang budidaya perikanan komoditas ikan patin. Nilai-nilai lokal yang dikembangkan menjadi sebuah kearifan lokal dan modal sosial bagi masyarakat untuk mengembangkan budidaya perikanan komoditas ikan patin sebagai landasan ekonomi masyarakat. Sambil menjunjung tinggi nilai-nilai lokal yang dimiliki, setiap masyarakat dengan tingkat inovatifnya memutuskan untuk mengadopsi budidaya komoditas ikan patin sebagai mata pencaharian baru dan kekuatan ekonomi baru dalam upaya memenuhi kebutuhan hidup keluarganya.

Keberadaan nilai-nilai lokal dalam kehidupan masyarakat menjadi dinamika tersendiri dalam proses adopsi inovasi yang terjadi. Adanya nilai-nilai lokal yang berkembang dalam kehidupan masyarakat ternyata telah menyakinkan sebagian besar masyarakat untuk mengadopsi inovasi budidaya komoditas ikan patin sebagai kontribusi perbaikan mata pencaharian. Selama ini mereka membutuhkan mata pencaharian baru untuk menyelesaikan permasalahan ekonomi yang dihadapi. Berikut ini adalah life story (Lampiran 7) dan beberapa hasil wawancara tentang nilai-nilai lokal yang muncul dalam kehidupan masyarakat pembudidaya, seperti yang dikemukakan oleh WT (informan dari kategori inovator, PNS, dan petani karet) berikut ini.

\begin{tabular}{|l|l|l|}
\hline Hasil Wawacara dengan Bahasa Lokal & Hasil Wawancara yang Diterjemahkan \\
"Kami ko masyarakat yang baasal dai & Kami ini masyarakat yang berasal dari rumpun \\
umpun dan suku yang samo, makonyo & dan kesukuan yang sama sehingga memiliki rasa \\
kami maaso badunsanak kasodonyo. & kekeluargaan dan rasa kebersamaan yang tinggi \\
Dek iko la manjadi warisan dai niniok & di antara sesamanya. Karena ini sudah menjadi \\
munyang kami baso kami ko & warisan dari para nenek moyang dan leluhur \\
badunsanak kasodonyo. Makonyo bilo & kami bahwa kita semuanya bersaudara sehingga \\
ado yang parolu bantuan, kami bantu. & apabila saudaramu membutuhkan bantuanmu, \\
Dek la maaso saumpun makonyo kami & maka bantulah mereka. Keserumpunan suku \\
maaso kuek untuok bisa tolong- & yang kami miliki menjadi kekuatan bagi kami \\
manolong. Apole kini dek krisis & untuk bisa saling tolong-menolong. Apalagi saat \\
moneter, kami maaso sanasib & terjadinya keterpurukan ekonomi yang melanda \\
sapanangguongan untuk basamo- & kami, kami memiliki rasa senasib dan \\
samo mancai jalan kolu. Makonyo dek & sepenanggungan untuk sama-sama keluar dari \\
ado piluang condo iko makonyo kami & keterpurakan itu sehingga begitu ada solusi dan \\
samo-maso bausaho untuok itu”. & jawaban dari keterpurukan ekonomi itu, maka \\
(Wawancara, 5 April 2019) & kami bahu-membahu untuk sama-sama keluar \\
dari keterpurukan tersebut.
\end{tabular}

Pernyataan yang sama tentang berkembangnya nilai-nilai lokal juga disampaikan oleh FE (informan dari ketegori pengikut dini, pembudidaya, dan pedagang) berikut ini. 


\begin{tabular}{|l|l|l|}
\hline Hasil Wawacara dengan Bahasa Lokal & Hasil Wawancara yang Diterjemahkan \\
"Patonak disiko baasal dai umpun & $\begin{array}{l}\text { Pembudidaya di sini merupakan masyarakat } \\
\text { dan suku yang samo. Walaupun ado }\end{array}$ & yang memiliki rumpun dan suku yang sama \\
yang babezo tapi ndak banyak do. Dek & walaupun ada beberapa yang berbeda, tetapi \\
maaso saumpun go la tuwun tamuwun & tidak banyak. Keserumpunan ini telah \\
baso awak ko badunsanak kasodonyo, & mewariskan kepada kami bahwa kita semua \\
makonyo harus saliong tolong- & bersaudara sehingga harus saling tolong- \\
manolong. Dek nilai ko la malokek & menolong di antara sesamanya. Karena nilai ini \\
dan tapaliao dimasyarakat kami & sudah terbudaya dan terpelihara dalam \\
disiko. Makonyo bilo ado yang parolu & kehidupan masyarakat di sini sehingga apabila \\
patolongan, kami sonang ati untuok & ada masyarakat yang membutuhkan bantuan, \\
manolongnyo". (Wawancara, 5 April & maka kita semua akan suka rela untuk \\
2019) & membantunya atas dasar kita semua adalah \\
& saudara.
\end{tabular}

Pendapat yang hampir sama tentang nilai-nilai lokal juga disampaikan oleh AM (informan pelengkap, yaitu Kasi Pemberdayaan Masyarakat Kecamatan XIII Koto Kampar) sebagai berikut.

\begin{tabular}{|c|c|}
\hline Iasil Wawacara dengan Bahasa Lokal & asil Wawancara yang Diterjemahkan \\
\hline $\begin{array}{l}\text { "Kaukunan patonak di Desa Koto } \\
\text { Masojik go tajago dengan elok. Yo ... } \\
\text { mungkin dek baasal dai umpun yang } \\
\text { samo. Sahinggo la maaso keluarga } \\
\text { kasodonyo yang saliong tolong } \\
\text { manolong. Buktinyo masyarakat akan } \\
\text { copek bilo ado yang parolu } \\
\text { patolongan. Contoh iko banyak dibuek } \\
\text { dek patonak ikan patin disiko, inyo } \\
\text { saliong tolong-manolong bilo ado } \\
\text { masala dalam batonak ikan. Makonyo } \\
\text { bilo ado masalah tontang batonak iko } \\
\text { inyo cai jalan kolu basamo-samo. } \\
\text { Condo itula tingginyo kekeluargaan } \\
\text { disiko". (Wawancara, } 5 \text { April 2019) }\end{array}$ & $\begin{array}{l}\text { Kerukunan pembudidaya di Desa Koto Mesjid } \\
\text { sangat terjaga dengan baik, ya ... mungkin } \\
\text { karena masyarakat di sana berasal dari satu } \\
\text { rumpun yang sama sehingga memiliki nilai } \\
\text { kekeluargaan, nilai kebersamaan dan nilai } \\
\text { tolong-menolong yang tinggi di antara } \\
\text { sesamanya. Buktinya masyarakat akan cepat } \\
\text { tanggap apabila ada masyarakat yang lain } \\
\text { membutuhkan pertolongan. Contoh ini banyak } \\
\text { ditunjukkan oleh para pembudidaya ikan patin di } \\
\text { sana, mereka akan saling membantu satu dengan } \\
\text { yang lainnya apabila ada permasalahan yang } \\
\text { dihadapi dalam berbudidaya sehingga setiap } \\
\text { permasalahan berbudidaya yang timbul akan } \\
\text { dipecahkan secara bersama-sama. Begitulah } \\
\text { tingginya nilai kekeluargaan, nilai kebersamaan, } \\
\text { dan nilai tolong-menolong yang dikembangkan } \\
\text { di sana. }\end{array}$ \\
\hline
\end{tabular}

Pernyataan dan pendapat di atas menjelaskan bahwa nilai-nilai lokal dalam kehidupan masyarakat telah ada dan terpelihara secara turun-temurun. Nilai-nilai lokal yang tumbuh merupakan warisan dari para lelehur dan nenek moyang mereka yang ditanamkan sejak dulu. Hal itu karena masyarakat desa berasal dari rumpun dan suku yang sama, yaitu Suku Minangkabau, yang secara turun-temurun memelihara nilai adat budaya yang tinggi. Walaupun tidak lagi tinggal di wilayah aslinya, nilai adat budaya Suku Minangkabau harus terus dilestarikan dan dijaga di manapun bumi dipijak. Prinsip penerapan nilai adat budaya bagi setiap keturunan Suku Minangkabau ini juga dipraktikkan oleh 
masyarakat di sini. Meskipun penerapan nilai adat budaya dari Suku Minangkabau tidak secara keseluruhan dapat dilakukan, beberapa nilai adat budaya yang penting masih dilaksanakan. Keberadaan nilai-nilai lokal yang ada pada masyarakat juga merupakan cerminan dari nilai adat budaya suku Minangkabau yang disebut dengan istilah basandi syarak, syarak basandi kitabullah (adat yang didasarkan/ditopang oleh syariat Islam berdasarkan pula pada Alquran dan hadis).

Masyarakat desa ini yang merupakan masyarakat keturunan Suku Minangkabau tentunya terus memelihara nilai adat budaya yang telh diwariskan. Nilai adat budaya yang dipraktikkan dalam kehidupan masyarakat menjadi nilai-nilai lokal yang menjadi ciri khas masyarakat. Nilai-nilai lokal yang berkembang dalam kehidupan masyarakat itu adalah nilai kekeluargaan, nilai kebersamaan, dan nilai senasib sepenanggungan. Nilai-nilai itu berkembang dengan sendirinya di dalam kehidupan bermasyarakat berdasarkan perjalanan waktu dan menjadi ciri tersendiri dalam kehidupan masyarakat. Dalam praktik berbudidaya komoditas ikan patin yang dilakukan oleh masyarakat, nilai-nilai lokal yang ada pada masyarakat menjadi faktor penentu kelancaran proses adopsi yang dilakukan. Hal itu disebabkan oleh nilai-nilai lokal yang ada dijadikan sebagai modal sosial bagi masyarakat untuk memulai mencoba dan memutuskan untuk ikut berbudidaya komoditas ikan patin.

Nilai-nilai lokal yang dimiliki oleh masyarakat ternyata telah memberikan kemudahan akses bagi setiap anggota masyarakat yang membutuhkan informasi dan pembelajaran budidaya komoditas ikan patin. Kemudahan akses yang diberikan disebabkan oleh perasaan serumpun dan para pembudidaya komoditas ikan patin merasa semua masyarakat desa ini adalah saudara. Sesama saudara harus dapat saling tolong dan saling merasakan kesusahan yang dialami oleh saudaranya. Realitas inilah yang terjadi saat awal-awal inovasi teknologi bidang perikanan dalam berbudidaya komoditas ikan patin ditemukan dan berhasil dipraktikkan. Beberapa anggota masyarakat menyakini bahwa nilai-nilai lokal yang dimiliki dapat membantunya mendapatkan kemudahan akses dalam mencari informasi dan proses pembelajaran terhadap budidaya komoditas ikan patin. Masyarakat yang berhasil membuktikan budidaya komoditas ikan patin dapat memberikan kontribusi perbaikan terhadap mata pencaharian baru yang dibutuhkan oleh masyarakat dengan sukarela membuka diri untuk memberikan informasi dan pembelajaran berbudidaya kepada setiap masyarakat yang membutuhkannya. Keterbukaan yang dilakukan oleh pembudidaya awal atau inovator terhadap akses informasi dan pembelajaran berbudidaya tidak terlepas dari nilai-nilai lokal yang telah berkembang selama ini dalam kehidupan masyarakat.

Nilai-nilai lokal terbukti sangat berperan penting dalam upaya penyebaran informasi atas keberhasilan budidaya komoditas ikan patin yang dilakukan oleh inovator. Nilai-nilai lokal yang dimiliki, bahkan menjadi penggerak awal bagi setiap anggota masyarakat yang ingin melakukan budidaya. Melalui nilai kekeluargaan, masyarakat awal mencoba mencari informasi terkait keberhasilan budidaya yang dilakukan oleh inovator. Apalagi budidaya komoditas ikan patin yang dilakukan ternyata menjanjikan keuntungan yang besar apabila dapat dikelola dengan baik. Berdasarkan nilai kekeluargaan yang telah terpelihara, inovator juga tidak ragu-ragu memberikan informasi yang dibutuhkan oleh setiap anggota masyarakat yang ingin belajar berbudidaya komoditas ikan patin. Dikatakan bahwa masyarakat akan sangat berhati-hati mencari informasi tentang keberhasilan berbudidaya, sebab sebelumnya mereka pernah mengalami kegagalan dalam berbudidaya. Pengalaman kegagalan yang dialami masyarakat membuat mereka benar-benar mencari informasi yang lengkap tentang berbudidaya komoditas ikan patin. Hal itu dilakukan supaya mereka tidak lagi mengalami kegagalan yang sama apabila memutuskan untuk berbudidaya komoditas ikan patin. Dengan demikian, melalui nilai kekeluargaan yang dimiliki, masyarakat meminta inovator untuk benar-benar mengajarkan cara budidaya yang benar agar dapat memperoleh hasil yang memuaskan. Nilai kekeluargaan yang berkembang di antara masyarakat membuat inovator dengan senang hati mengajarkan cara budidaya komoditas ikan patin yang benar. Dengan demikian, nilai kekeluargaan yang ada menjadi jembatan bagi setiap masyarakat untuk dapat belajar dan dibimbing mempraktikkan budidaya komoditas ikan patin. 
Selain nilai kekeluargaan yang tumbuh dalam praktik budidaya komoditas ikan patin, ada juga nilai-nilai lokal lainnya yang berkembang, seperti nilai kebersamaan dan nilai senasib sepenanggungan. Nilai-nilai lokal ini berfungsi di saat para pembudidaya dari kelompok yang tidak memiliki hubungan keluarga dengan inovator melakukan adopsi. Dengan adanya nilai kebersamaan dan nilai senasib sepananggungan, inovator tetap membukakan jalan dan akses kepada setiap masyarakat yang ingin berbudidaya komoditas ikan patin. Pembelajaran dan bimbingan yang dilakukan inovator kepada masyarakat pembudidaya yang tidak memiliki hubungan keluarga tidak terlepas dari rasa kebersamaan dan rasa senasib sepananggungan yang dulunya pernah dialami bersama. Sebelum munculnya inovasi budidaya komoditas ikan patin, masyarakat hidup dalam keterpurukan ekonomi yang sama dan memiliki nasib yang sama. Mereka, bahkan berusaha mencari solusi untuk keluar dari keterpurukan ekonomi secara bersama dan dengan aktivitas yang sama. Kebersamaan masyarakat dalam keterpurukan ekonomi yang sama mengembangkan nilai kebersamaan dan nilai senasib sepenanggungan yang tinggi di antara sesamanya.

Nilai-nilai lokal yang tumbuh dalam kehidupan masyarakat dan terpelihara dengan baik ternyata menjadi modal sosial dalam proses adopsi budidaya komoditas ikan patin. Nilai-nilai lokal yang ada memberikan peluang kepada masyarakat untuk percaya dan yakin terhadap masyarakat lainnya dalam memberikan pinjaman bibit dan pakan untuk memulai budidaya komoditas ikan patin. Kepercayaan dan keyakinan yang dimiliki oleh pembudidaya yang mempunyai pembibitan dan pembuatan pakan untuk memudahkan masyarakat yang ingin mencoba berbudidaya dalam bentuk pinjaman. Hal itu tidak terlepas dari telah terbudayanya nilai-nilai lokal yang ada dalam masyarakat. Di saat masyarakat tidak memiliki modal awal dalam berbudidaya komoditas ikan patin, bahkan inovator juga tetap mencarikan solusi pinjaman modal kepada pihak ketiga dengan memberikan jaminan bahwa masyarakat dapat mengembalikan pinjaman modal yang dilakukan. Bentuk-bentuk kemudahan akses yang dilakukan oleh inovator kepada seluruh masyarakat yang mengadopsi budidaya komoditas ikan patin didasari oleh nilai kekeluargaan, kebersamaan, dan senasib sepenanggungan yang telah udah tumbuh secara turun temurun. Oleh karenanya, nilai-nilai lokal yang ada di dalam kehidupan masyarakat menjadi faktor penentu terhadap lancarnya proses adopsi inovasi yang dilakukan.

\section{KESIMPULAN}

Dinamika proses adopsi inovasi yang berlangsung di Kawasan Minapolitan Desa Koto Mesjid mengandung nilai-nilai lokal sebagai faktor penentunya. Keberadaan nilai-nilai lokal yang telah diwariskan oleh para lelehur ternyata mampu menjadi jembatan penghubung bagi masyarakat untuk dibimbing dan diarahkan dalam proses budidaya komoditas ikan patin. Nilai-nilai lokal yang berkembang dan terbudaya dengan baik dalam kehidupan masyarakat disebabkan oleh asal mereka yang dari rumpun etnik yang sama, yaitu Suku Melayu Daratan. Suku Melayu Daratan yang ada di Kabupaten Kampar pada dasarnya merupakan keturunan Suku Minangkabau yang berasal dari Sumatera Barat. Masyarakat Suku Minangkabau dalam kehidupan sosialnya sangat teguh menjalankan nilai adat budaya yang telah diwariskan para pendahulunya. Dalam masyarakat Suku Minangkabau, nilai adat budaya yang diwariskan dikenal dengan istilah basandi syarak, syarak basandi kitabullah, yaitu adat yang didasarkan/ditopang oleh syariat agama Islam yang berdasarkan pula pada Alquran dan hadis. Nilai adat basandi syarak, syarak basandi kitabullah dalam budaya Suku Minangkabau memiliki enam kategori nilai, yaitu ketuhanan, kemanusian, persaudaraan, kesatuan dan persatuan, musyawarah dan demokrasi, ahlak dan budi pekerti, sertanilai gotong royong/sosial kemasyarakatan. Keenam nilai ini harus dijunjung tinggi dan dipraktikkan bagi setiap anak keturunan suku Minangkabau di mana pun mereka berdomisili. 
Masyarakat desa ini yang merupakan keturunan suku Minangkabau pada dasarnya juga mempraktikkan nilai adat budaya basandi syarak, syarak basandi kitabullah di dalam kehidupannya. Namun, praktik nilai adat budaya yang dikerjakan tidak mencakup keseluruhan nilai-nilai yang ada. Hal ini karena masyarakat tidak lagi berdomosili di wilayah suku Minangkabau, yaitu wilayah Sumatera Barat. Dengan demikian, dalam mempraktikkan nilai adat budaya yang diwariskan, mereka menyesuaikan dengan kondisi wilayah yang ditempati oleh masyarakat keturunan suku Minangkabau tersebut. Nilai adat budaya yang dipraktikkan akan menjadi nilai-nilai lokal yang berkembang, tumbuh, dan terbudaya dalam setiap sendi-sendi kehidupan masyarakat tersebut.

Nilai-nilai lokal yang tumbuh dan berkembang serta terbudaya dalam kehidupan masyarakat di Desa Koto Mesjid adalah sebagi berikut.

Pertama, nilai kekeluargaan merupakan suatu nilai yang menekankan kepada setiap individu masyarakat tentang persaudaraan. Artinya bahwa masyarakat yang berasal dari rumpun etnik dan suku yang sama harus memiliki pandangan dan pemikiran bahwa mereka semua adalah saudara. Dengan adanya nilai kekeluargaan ini, setiap individu masyarakat harus mampu saling tolong. Keterikatan nilai kekeluargaan yang dimiliki juga akan menciptakan hubungan silaturahmi yang harmonis antara masyarakat sehingga hubungan sosial yang dikembangkan menjadi lebih dinamis.

Kedua, nilai kebersamaan merupakan suatu nilai yang menekankan bahwa setiap individu masyarakat pada dasarnya memiliki hak dan kewajiban yang sama untuk memperoleh sesuatu yang ada di desa. Hal itu berarti masyarakat memiliki persamaan hak dan kewajiban untuk memberikan dan menerima informasi yang dibutuhkan oleh masyarakat lainnya dalam kehidupan sosial. Dengan demikian, nilai kebersamaan ini mengarahkan kepada setiap individu masyarakat untuk dapat bekerja sama dan bergotong royong antara sesama masyarakat dalam setiap menghadapi permasalahan sosial yang datang di desa tersebut. Rasa kebersamaan yang dimiliki masyarakat tentunya akan mengikat hubungan kekeluargaan yang erat di antara sesamanya guna mengatasi permasalahan kehidupan yang dihadapi masyarakat.

Ketiga, nilai senasib sepenanggungan merupakan suatu nilai yang menekankan sifat kepedulian dari setiap individu masyarakat dengan individu masyarakat lainnya dalam desa tersebut. Rasa kepedulian yang tinggi dalam diri masyarakat akan melahirkan sikap tolong di antara masyarakat. Bentuk kepedulian yang muncul dalam diri masyarakat dapat bersifat moral maupun materal untuk menyelesaikan permasalahan yang dihadapi. Dengan tingginya sifat kepedulian yang muncul, masyarakat yang mengalami kesusahan dalam kehidupannya akan merasa diperhatikan oleh masyarakat lainnya yang peduli dengan kondisi sosial yang dialami. Nilai senasib sepenanggungan juga muncul karena seluruh masyarakat di desa tersebut pernah mengalami kesusahan ekonomi bersama. Peristiwa itu membuat setiap masyarakat memiliki rasa peduli yang tinggi dengan sesamanya, yang akhirnya berkembang menjadi nilai yang dijunjung tinggi untuk dilaksanakan.

Dalam praktik adopsi inovasi budidaya komoditas ikan patin, nilai-nilai lokal yang dimiliki oleh masyarakat telah menjadi faktor penentu bagi berlangsungnya proses adopsi. Nilai-nilai lokal, seperti nilai kekeluargaan, nilai kebersamaan, dan nilai senasib sepenanggungan, telah mampu menjadi modal sosial bagi masyarakat sehingga tercipta kelancaran dalam proses adopsi yang dilakukan.

\section{SARAN}

Penerapan adopsi inovasi di setiap wilayah memiliki kultur yang berbeda-beda, maka akan lebih baik jika adopsi inovasi teknologi memperhatikan karakteristik wilayah, masyarakat, dan calon adopter yang ada. Kemudian proses adopsi inovasi yang relevan untuk suatu wilayah dipelajari dengan tidak hanya memberikan informasi dan pengetahuan saja, tetapi diperlukan pembuktian dan janji keuntungan 
(rewards) dari inovasi yang dikenalkan. Selanjutnya perlu memperhatikan nilai-nilai lokal sebagai dinamika adopsi inovasi yang berfungsi sebagai penghubung kelancaran adopsi inovasi. Keberhasilan penerapan adopsi inovasi teknologi bidang perikanan di Kawasan Minapolitan Desa Koto Mesjid, Provinsi Riau yang telah memberikan kontribusi terhadap perbaikan mata pencaharian bagi masyarakat, hal itu berimplikasi kepada kebijakan penetapan wilayah Kawasan Minapolitan yang merupakan sentra produksi pengelolaan produk yang berasal dari komoditas ikan patin. Perlu dilakukan pengembangan inovasi-inovasi terbaru dalam pengelolaan produk dengan komoditas ikan patin. Peluang inovasi baru itu muncul dari pengelolaan produk ikan asap/salai yang masih bersifat tradisional, limbah minyak ikan asap/salai yang belum termanfaatkan, dan pemasaran produk yang membutuhkan pengemasan yang mengangkat ciri-ciri lokal.

\section{DAFTAR PUSTAKA}

[1]. Albury David., 2003., Innovation in the Public Sector. Discussion paper., The Mall., London.

[2]. Agustin Irdiani., 2012., Peran Knowledge Sharing Di Kalangan Karyawan (Studi Deskriptif Pada Pt. Perusahaan Listrik Negara (Persero) Distribusi Jawa Timur)., Jurnal Ilmu Informasi dan Perpustakaan., Fisip - Unair., Surabaya.

[3]. Burhan Bungin., 2011., Penelitian Kualitatif : Komunikasi, Ekonomi, Kebijakan Publik dan Ilmu Sosial Lainnya., Edisi Kedua., Kencana Prenada Media Group., Jakarta.

[4]. Elok Mulyoutami, Endy Stefanus, Win Schalenbourg, Subekti Rahayu dan Laxman Joshi., 2005., Pengetahuan Lokal Petani Dan Inovasi Ekologi Dalam Konservasi Dan Pengolahan Tanah Pada Pertanian Berbasis Kopi Di Sumberjaya Lampung Barat., Word Agroforestry Center - ICRAF., Bogor.

[5]. Emzir, Prof. Dr. M.Pd., 2012., Metodologi Penelitian Kualitatif : Analisis Data., Raja Grafindo Persada., Jakarta.

[6]. Everett M. Rogers dan F. Floyd Shoemaker., 1971., Memasyarakatkan Ide-ide Baru., Penyusun Abdillah Hanafi., Penerbit Usaha Nasional., Surabaya.

[7]. Halvorsen, Thomas, et al., 2005. On the Differences between Public and Private Sector Innovations., Publin Report., Oslo.

[8]. Heti Resnawati., 2012., Inovasi Teknologi Pemanfaatan Bahan Pakan Lokal Mendukung Pengembangan Industri Ayam Kampung., Volume 5 Nomor 2., Jurnal Pengembangan Inovasi Pertanian., Bogor.

[9]. Jauhari Efendy dan Yanter Hutapea., 2010., Analisis Adopsi Inovasi Teknologi Pertanian Berbasis Padi di Sumatera Selatan Dalam Perspektif Komunikasi., Jurnal Pengkajian dan Pengembangan Teknologi Pertanian Vol.13 No. 2.

[10]. Jhon W. Creswell., 2012., Research Design : Pendekatan Kuantitatif, Kualitatif dan Mixed., Pustaka Pelajar., Yogyakarta. 
[11]. Mahdita Paramita., 2014., Dinamika Inovasi dalam Kebijakan Perumahan Pemerintah Daerah di Era Desentralisasi., Desertasi Studi Kebijakan., Sekolah Pascasarjana UGM.

[12]. Margono Slamet., 1978., Kumpulan Bahan Bacaan Penyuluhan Pertanian., Institut Pertanian Bogor.

[13]. Nonaka Ikujiro and Hirotaka Tekauchi., 1995., The Knowledge Creating Company How Japanese Corporation Create The Dynamic of Innovation., Oxford University Press., New York.

[14]. Rogers, E.M., 2003., Diffusion of Innovations 5thedition., Free Press. New York.

[15]. Welli Yuliatmoko., 2011., Inovasi Teknologi Produk Pangan Lokal Untuk Percepatan Ketahanan Pangan., Universitas Terbuka., Jakarta.

[16]. Yapeng Zhu., 2013., Policy Entrepreneurship, Institutional Constraints, and Local Policy Innovation in China., China Review, Vol. 13, No. 2, pp. 97-122., Chinese University Press

[17]. Yovita Anggita Dewi., 2012., Inovasi Spesifik Lokasi Untuk Inkubator Teknologi Mendukung Pengembangan Ekonomi Lokal., Volume 10 Nomor 4., Jurnal Analisis Kebijakan Pertanian.

[18]. Yogi Suwarno., 2008., Inovasi di Sektor Publik., Penerbit STIA - LAN Press., Jakarta. 